\title{
Science, Diplomacy, and the Red Sea's Unique Coral Reef: It's Time for Action
}

\author{
Karine Kleinhaus ${ }^{1,2 *}$, Ali Al-Sawalmih ${ }^{3,4}$, Daniel J. Barshis ${ }^{5}$, Amatzia Genin ${ }^{6,7}$, \\ Lola N. Grace ${ }^{8}$, Ove Hoegh-Guldberg ${ }^{9}$, Yossi Loya ${ }^{10}$, Anders Meibom ${ }^{11,12}$, \\ Eslam O. Osman ${ }^{13+}$, Jean-Daniel Ruch ${ }^{14}$, Yonathan Shaked ${ }^{7}$, Christian R. Voolstra ${ }^{15}$, \\ Assaf Zvuloni ${ }^{16}$ and Maoz Fine ${ }^{7,17}$
}

\section{OPEN ACCESS}

Edited by:

Stefano Goffredo,

University of Bologna, Italy

Reviewed by:

Lyndon Mark DeVantier,

Coral Reef Research, Australia

Douglas Fenner,

Independent Researcher, Pago Pago,

American Samoa

*Correspondence:

Karine Kleinhaus

kleink03@nyu.edu

tORCID:

Eslam O. Osman

orcid.org/0000-0002-5517-8186

Specialty section:

This article was submitted to

Coral Reef Research,

a section of the journal

Frontiers in Marine Science

Received: 06 November 2019

Accepted: 03 February 2020

Published: 26 February 2020

Citation:

Kleinhaus K, Al-Sawalmih A

Barshis DJ, Genin A, Grace LN,

Hoegh-Guldberg O, Loya Y,

Meibom A, Osman EO, Ruch J-D,

Shaked Y, Voolstra CR, Zvuloni A and

Fine M (2020) Science, Diplomacy, and the Red Sea's Unique Coral Reef:

It's Time for Action.

Front. Mar. Sci. 7:90.

doi: 10.3389/fmars.2020.00090
1 School of Marine and Atmospheric Sciences, Stony Brook University, Stony Brook, NY, United States, ${ }^{2}$ College of Global Public Health, New York University, New York, NY, United States, ${ }^{3}$ Marine Science Station, University of Jordan, Aqaba, Jordan, ${ }^{4}$ Max Planck Institute of Colloids and Interface, Potsdam, Germany, ${ }^{5}$ Department of Biological Sciences, Old Dominion University, Norfolk, VA, United States, ${ }^{6}$ Department of Ecology, Evolution and Behavior, Hebrew University of Jerusalem, Jerusalem, Israel, ${ }^{7}$ Interuniversity Institute for Marine Sciences, Eilat, Israel, ${ }^{8}$ Middle East Children's Institute, Locust Valley, NY, United States, ${ }^{9}$ Global Change Institute, The University of Queensland, St Lucia, QLD, Australia, ${ }^{10}$ School of Zoology, The George S. Wise Faculty of Life Sciences, Tel Aviv University, Tel Aviv, Israel, " Laboratory for Biological Geochemistry, School of Architecture, Civil and Environmental Engineering, Ecole Polytechnique Fédérale de Lausanne, Lausanne, Switzerland, ${ }^{12}$ Center for Advanced Surface Analysis, Institute of Earth Sciences, University of Lausanne, Lausanne, Switzerland, ${ }^{13}$ Department of Biology, Eberly College of Science, The Pennsylvania State University, University Park, PA, United States, ${ }^{14}$ Ambassador of Switzerland in Israel, Tel Aviv, Israel, ${ }^{15}$ Department of Biology, University of Konstanz, Konstanz, Germany, ${ }^{16}$ Israel Nature and Parks Authority, Jerusalem, Israel, ${ }^{17}$ The Mina \& Everard Goodman Faculty of Life Sciences, Bar-llan University, Ramat Gan, Israel

Rapid ocean warming due to climate change poses a serious risk to the survival of coral reefs. It is estimated that 70-90 percent of all reefs will be severely degraded by mid-century even if the $1.5^{\circ} \mathrm{C}$ goal of the Paris Climate Agreement is achieved. However, one coral reef ecosystem seems to be more resilient to rising sea temperatures than most others. The Red Sea's reef ecosystem is one of the longest continuous living reefs in the world, and its northernmost portion extends into the Gulf of Aqaba. The scleractinian corals in the Gulf have an unusually high tolerance for the rapidly warming seawater in the region. They withstand water temperature anomalies that cause severe bleaching or mortality in most hard corals elsewhere. This uniquely resilient reef employs biological mechanisms which are likely to be important for coral survival as the planet's oceans warm. The Gulf of Aqaba could potentially be one of the planet's largest marine refuges from climate change. However, this unique portion of the Red Sea's reef will only survive and flourish if serious regional environmental challenges are addressed. Localized anthropogenic stressors compound the effects of warming seawater to damage corals and should be mitigated immediately. Reefs in the rest of the Red Sea are already experiencing temperatures above their thermal tolerance and have had significant bleaching, though they too would benefit from fewer local anthropogenic stressors. The countries bordering the entire Red Sea will need to cooperate to enable effective scientific research and conservation. The newly established Transnational Red Sea Center, based at the Ecole Polytechnique Fédérale de Lausanne (EPFL), can serve as the regionally inclusive, neutral organization to foster crucial regional scientific collaboration.

Keywords: Red Sea, coral reef, coral bleaching, climate change, science diplomacy 


\section{INTRODUCTION}

Over half a billion people globally depend on coral reef ecosystems for food, income from tourism and fisheries, and coastal protection (Hoegh-Guldberg, 2011). An estimated 25 percent of all marine species depend on coral reefs during at least some portion of their life cycle (NOAA, 2019a). The impending loss of the world's coral reefs threatens the health and socioeconomic well-being of hundreds of millions of people and could substantially disrupt multiple marine ecosystems. The Red Sea's reef is one of the longest continuous living reefs in the world. It extends along 4,000 $\mathrm{km}$ of the Red Sea's shorelines, ranges from 12.5 to $29.5^{\circ} \mathrm{N}$ latitude (Voolstra and Berumen, 2019). Its exceptionally broad latitudinal temperature gradient (Figure 1), ranging from a maximum of $28^{\circ} \mathrm{C}$ in the northern tip of the Gulf of Aqaba to a maximum of $34^{\circ} \mathrm{C}$ in the Dahlak Archipelago in the south, makes the Red Sea an invaluable natural laboratory in which to study the effects of ocean warming on reef ecosystems (Berumen et al., 2019). Moving from north to south, the reefs are exposed to progressively warmer waters, as if moving along a timeline into future oceans. Another unique feature of the Red Sea is the Gulf of Aqaba, in the north. The Gulf is a coral refuge from climate change. Its corals are exceptionally resistant to thermal stress with regard to their summer Mean Monthly Maximum [MMM] temperature (Fine et al., 2013; Bellworthy and Fine, 2017; Krueger et al., 2017; Osman et al., 2018). It is hypothesized that by the time the reefs of the Gulf of Aden and the southern Red Sea (as well as many other Indo-Pacific reefs) cross their thermal bleaching thresholds, the corals in the Gulf of Aqaba will still be well below theirs (Fine et al., 2013).

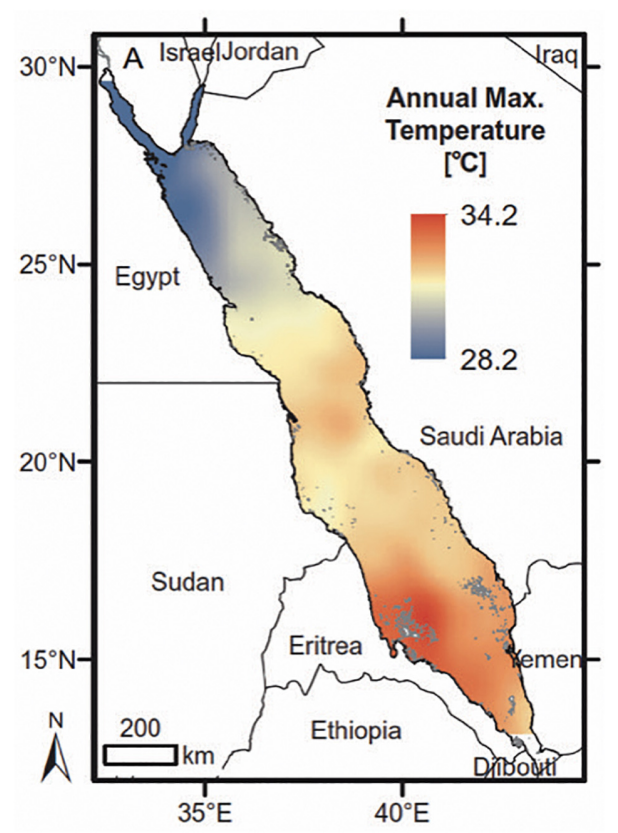

FIGURE 1 | The Sea Surface Temperature (SST) gradient across the Red Sea. Shown are the highest recorded SSTs during the period of 1982-2015 (modified from Fine et al., 2019).
The coral reefs of the Red Sea provide food and a source of livelihood to a rapidly growing population of over 28 million people living along its coastline. Fisheries landed value is approximately US $\$ 230$ million per year for the region, while annual revenues from tourism are over US $\$ 12$ billion (Barbière, 2019). A biodiversity hotspot, the Red Sea has a high degree of endemism (Dibattista et al., 2016; Osman et al., 2020). Its unique reefs are also a rich potential source of natural products and medicines (Shaala et al., 2015; Ibrahim et al., 2017). The high degree of endemism and adaptation to high salinity and high temperature could potentially have led to the appearance of unique molecules and metabolites not to be found in other reef systems of the world (O'Rourke et al., 2016, 2018; Kremb et al., 2017). The biodiversity that is found only on healthy reefs is considered by scientists to be key to finding new medicines for the 21st century. Many therapeutics are now being developed from coral reef animals and plants as possible cures for cancer, arthritis, human bacterial infections, viruses, and other diseases (Malve, 2016; NOAA, 2019b). For example, the antiviral drugs Ara-A and $\mathrm{AZT}$ and the anticancer agent Ara- $\mathrm{C}$ were developed from extracts of sponges found on a Caribbean reef (Bruckner, 2002).

For future generations to benefit from this stockpile of potential resources, and for the reef to endure and thrive, a variety of serious regional environmental challenges must be addressed. The countries bordering the Red Sea will need to cooperate for efficient and effective research and conservation of the Red Sea's coral. Because of political tensions, regional cooperation on research and management would be greatly facilitated by the involvement of a neutral organization. The Transnational Red Sea Center was established in March 2019 as a neutral organization to foster effective regional scientific collaboration. It is based at the Ecole Polytechnique Fédérale de Lausanne (EPFL), a world-renowned academic institution (A Research Center to Protect the Red Sea Ecosystem, 2019).

\section{REGIONAL CHALLENGES FACING THE RED SEA'S REEF ECOSYSTEM}

The Red Sea, like other marine ecosystems, experiences global warming and ocean acidification (Steiner et al., 2018). However, corals in the Red Sea's Gulf of Aqaba have an exceptionally high bleaching threshold. A $6^{\circ} \mathrm{C}$ gap exists between the average summer maximum temperature of $\sim 26^{\circ} \mathrm{C}$ (The Israel National Monitoring Program at the Gulf of Eilat - Available Data, 2019) and the predicted bleaching threshold of $32^{\circ} \mathrm{C}$ or higher for corals in the Gulf, making the Gulf a coral refuge from climate change (Fine et al., 2013). Climatic models predict an increasing frequency and intensity of heatwaves (Osman et al., 2018; Genevier et al., 2019) which may bring about extreme warm weather to the Red Sea region sooner than is predicted by the measured warming trend. These climatic models add some uncertainty to the robustness of the coral reef refuge in the Gulf of Aqaba. Yet, it must be remembered that a $6^{\circ} \mathrm{C}$ gap allows for robust thermal tolerance. Besides, contrasting models suggests that natural climate oscillations may counteract the warming trend observed at present (Krokos et al., 2019). 
Currently, sea surface temperatures in the Gulf of Aqaba range annually from 21 to $26^{\circ} \mathrm{C}$ (The Israel National Monitoring Program at the Gulf of Eilat - Available Data, 2019). There is a low variation of temperatures between depths, with only a $0.3^{\circ} \mathrm{C}$ difference in average yearly temperatures between shallow and mesophotic waters (Eyal et al., 2019). The Red Sea overall is characterized by warm deep water; at $700 \mathrm{~m}$ depth the average temperature is $21^{\circ} \mathrm{C}$ (Eyal et al., 2019). Although a portion of the Red Sea's reef is particularly resistant to rising sea temperatures at this time (Fine et al., 2013; Roder et al., 2013; Bellworthy and Fine, 2017; Grottoli et al., 2017; Krueger et al., 2017; Osman et al., 2018), the ability of these corals, and that of corals generally, to withstand global environmental changes depends in part on the extent to which regional and local disturbances deplete their physiological reserves (Hughes and Connell, 1999; Ateweberhan et al., 2013; Bozec and Mumby, 2015). Regional or local stressors can bring corals closer to their resistance thresholds, beyond which they will bleach and degrade (Figure 2).

There are increasing demands on the Red Sea's resources that escalate the urgency for regional cooperation on research and conservation of the Sea's corals. The U.N. ranked the regional population as highly vulnerable on average because of low income and poor resources for healthcare and education, and there is a high threat of degradation of the Red Sea reef ecosystem due to overexploited fisheries, pollution levels, and damage to coastal environments from development (Barbière, 2019). One key pressure on the reef is the expanding population and development of the coastline. While stretches of the coast are still sparsely populated, larger towns and cities continue to grow along the Red Sea, and these areas generate substantial local pressure on its reefs. Some portions of the reef have already been heavily damaged by uncontrolled tourism; human population expansion and coastal development resulting in sewage, agricultural and pesticide runoff and associated declines in water quality; mariculture which pollutes and increases turbidity; and overfishing (Burke et al., 2011; Steiner et al., 2018).

One major anticipated pressure in the region is the construction of the megacity of Neom, which is planned to cover 10,230 square miles along the shores of the Red Sea, centered in the Kingdom of Saudi Arabia but including territory from Egypt and Jordan. This initiative is part of the Kingdom's drive to diversify its economy and shift away from fossil fuels. The Kingdom envisions a cross-border city that will be carbon neutral and rely exclusively on renewable energy (Neom, 2019). A Red Sea Tourism Project is also being developed in the Kingdom and plans for more than 10,000 hotel rooms and luxury residences across dozens of pristine islands and over 100 miles of coastline in the Red Sea. Ecotourism including snorkeling and diving will be a focus of this project, so the value of the Red Sea's reefs will continue to grow as a major economic asset. According to the state-owned Red Sea Development Company (TRSDC), the project is expected to create up to 70,000 jobs and to contribute $\$ 5.3$ billion to the nation's GDP (Red Sea The Project, 2019). However, extensive construction, desalination plants, sewage plants and tourism, including diving and snorkeling, will increase pressures on the reef along the shores of Neom and the islands project, unless the planned for creative, broad, and science-based conservation management is successfully enacted. Conservation efforts on such a broad scale also highlight the value of regional collaboration and additional scientific research. A current concern in Saudi Arabia is the pollution being released off of the Jeddah Corniche. The rapidly expanding city is

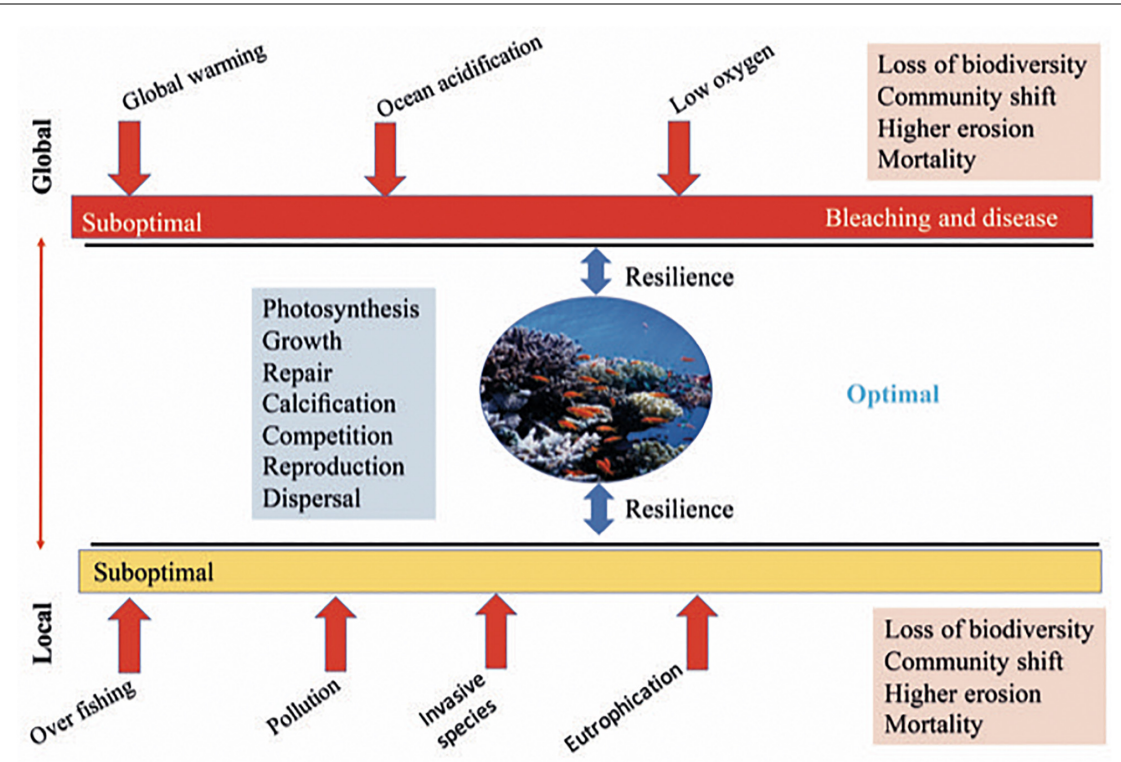

FIGURE 2 | Coral reefs are deteriorating from global environmental stressors such as global warming, ocean acidification, and reduced ocean oxygen concentrations. The resistance and resilience of coral reefs to global stressors will require the reduction of local stressors such as overfishing, pollution, invasive species, and eutrophication which act individually, or in combination with each other and/or with global stressors to reduce resistance. This may result in loss of biodiversity, community shift, higher erosion, and mortality, once physiological and ecological thresholds have been exceeded. 
producing large amounts of municipal wastewater, which far exceed the capacity of the sewage treatment stations. Treated and untreated sewage is dumped directly at discharge points along Jeddah coast, and both nutrients and trace metals are detectable next to the fringing reefs that line the shore; these pollutants can damage reef ecosystems (Al-Farawati et al., 2011; Ziegler et al., 2016, 2019). Regionally agreed upon standards and support for development of adequate treatment facilities and environmental policies could help to remediate this damaged portion of the reef.

Other countries along the Red Sea are also projected to exert increasing pressure on the reef. The population of Eilat, which lies on the western shore of the Gulf of Aqaba, grew by $65 \%$ from 1995 to 2018 (Brinkhoff, 2019). A newly opened, high-capacity international airport is expected to increase the number of visitors to the region as well, potentially intensifying anthropogenic stress on coral reefs in the Gulf, which to date contains arguably the most robust section of the Red Sea's reef, as noted above. Israel's fish farms polluted the Gulf of Eilat/Aqaba for almost 20 years, harming the reefs and damaging seagrass beds in the northern Gulf (Loya et al., 2004). They were removed in 2008 after a long debate and involvement of an international committee of experts. However, in 2019 Israel announced its intention to invest in a mariculture center in Eilat that will use water from the Gulf of Aqaba and recycle it back (Government decision 4848), putting reef ecosystems at major risk of damage from increasing levels of aquaculture effluents that include high levels of antibiotics, bacterial and viral pathogens, as well as turbidity due to nutrient run off. Strong advocacy is needed to prevent this potentially significant source of damage to the reef. One potential alternative may be diverting the returning water to the planned Red Sea-Dead Sea canal, described below, which will take the effluent nutrient-rich water toward the Dead Sea.

The city of Aqaba, Jordan, is twice the size of Eilat. It is also planning to expand substantially in the coming years. The population of Aqaba has grown by 85\% from 2004 to 2015 and has significant projects for additional development that are in various stages of completion, such as the Ayla Oasis project (Brinkhoff, 2017; Ayla Oasis Development, 2019). Although ecological considerations are part of these development plans, a meticulous, science-based approach to construction will be required here as well to minimize damage to the unique reefs of the Gulf of Aqaba.

Egypt has almost $1500 \mathrm{~km}$ of coastline along the Red Sea with several world-renowned diving destinations such as Sharm El Sheikh and Hurghada that significantly benefit the Egyptian economy via profits from tourism; for example, an estimate of recreational reef-related expenditures in Egypt was $\$ 472$ million in 2000 (Cesar, 2003). Egypt initiated one of the earliest conservation efforts in the Red Sea with the establishment, in 1983, of the Ras Mohammad National Park (Ras Mohammed National Park, 2019). Its purpose is to protect the marine wildlife and lush reefs from fishing and other human activities, such as coastal development. However, challenges to the reef's health and survival are also emerging in Egypt. A recent study of Landsat data that was collected from 1973-2015 measured a loss of 6.21 square kilometers of coral cover and an increase of 13.4 square kilometers of coastal development along the reef in Egypt's
Hurghada region, on the northern Red Sea coast (Khaled, 2019). The researchers estimated that this loss of coral cover during those 42 years led to a total economic loss of over $\$ 18$ billion and a loss of fish production of approximately 80 metric tons. They also recommended an extensive monitoring program to track impacts from development, reduction of tourism impacts, reduction of overfishing, and development of a robust coastal zone planning program (Khaled, 2019). Egypt's Suez Canal is an enormously important passageway for oil and commercial tankers. In 2018, a total of 18,174 commercial vessels passed through the canal, some of which carry oil and present a risk of oil leaks and damage to the northern Red Sea's reef (Suez Canal Traffic Statistics Annual Report 2018, 2019). The reefs are also threatened by potential oil spillage from oil pipelines and offshore storage facilities. In the southern-most section of the Red Sea the SAFER tanker, a floating oil storage and offloading unit (FSO) anchored off the coast of Yemen, holds 1.1 million barrels of oil and has begun to leak its cargo, a consequence of political and military conflicts in the area which hamper remediation and international intervention (World Maritime News, 2019). In October 2019, an Iranian tanker carrying approximately one million barrels of crude oil was attacked off the Saudi Arabian coast of Jeddah (Wintour, 2019). While the spill event was quickly contained, tankers could potentially become more frequent targets in the region. This would put reefs and millions of people (through damage to fisheries, water desalination capabilities, and loss of income from tourism) at immediate risk. Science-based conservation measures must expand across borders in order to address this pressing threat to the Red Sea's reef.

In September 2019, scientists identified a silent threat to the persistence of coral in the northern Red Sea's Gulf of Aqaba: a loss of synchronized mass spawning for certain key species (Shlesinger and Loya, 2019). If spawning is not synchronized then fewer new corals are produced, which compromises the ability of the reef to maintain itself in a healthy state and recover following disturbances. Possible causes for the loss of synchronization may include various forms of pollution and ocean warming. These changes need to be considered in future research (Shlesinger and Loya, 2019).

\section{CURRENT LEVEL OF REGIONAL SCIENTIFIC COOPERATION TO STUDY, MONITOR, AND PROTECT THE RED SEA'S REEF}

Despite existing environmental stressors and newly emerging threats to the Red Sea's unique coral, there are currently no coordinated scientific research or management efforts that encompass the entire Red Sea reef complex. This is at odds with the growing number of examples of regional approaches to the management of reefs elsewhere (e.g. Great Barrier Reef Marine Park, Coral Triangle Initiative, Mesoamerican Reef system). Reef-wide research, standardized data collection, longterm monitoring, and integrated management are crucial to effectively study the mechanisms of coral resilience in the face of 
warming oceans, and to plan and execute management strategies to mitigate the damage from regional environmental stressors; but these are lacking. The Red Sea is bordered by eight countries, some of which have no official ties with each other or are in active conflict. The contentious political climate in the region presents a significant challenge to scientific cooperation, although this cooperation is urgently needed.

There have been previous initiatives combining science and diplomacy in the region. For example, in 1994, during the Peace Negotiation between Jordan and Israel, the countries agreed to develop four initiatives: (1) municipal cooperation between Aqaba, Jordan, and Eilat, Israel, which are neighboring cities along the Gulf of Aqaba; (2) the Joint Oil Spill Response Plan for the northern Gulf of Aqaba; (3) the Red Sea Dead Sea Canal; (4) a government-funded joint long-term monitoring program to gather and share essential data in order for scientists and planners to understand long-term trends in ecosystem conditions and determine the ecological and socio-economic impact of various management strategies for the Gulf of Aqaba (Portman and TeffSeker, 2017). The goals included collaboration on research on coral reefs and marine biology, and implementation of policies and regulations designed to protect the coral reefs. However, there has been less cooperation over the past decade as regional political tension has grown. In the last several years there has been a renewed interest in the Red Sea Dead Sea Canal, which is planned to pump water from the Red Sea into a desalination facility in Aqaba to provide drinking water for Jordan and the Palestinian territories, while the brine byproduct would be piped 125 miles northwards to be deposited in the Dead Sea, which is shared by Jordan and Israel (Red Sea-Dead Sea Water Conveyance Study Environmental and Social Assessment, 2014). Despite years of debate and revised designs, funding has yet to be secured for this project and there are still concerns about its effects on the reef (Fischhendler and TenenboimWeinblatt, 2019; Whitman, 2019). Another important example of cross-border cooperation in the Red Sea is PERSGA, the Regional Organization for the Conservation of the Environment of the Red Sea and Gulf of Aden. Announced in 1995, it is an intergovernmental body headquartered in Saudi Arabia that falls under the umbrella of the Arab League. Its mission is to conserve the coastal and marine environments of the Red Sea and Gulf of Aden. PERSGA also aims to educate and develop the capacity of rangers for Marine Protected Areas and provide technical support and coordinate marine monitoring programs across its member countries (PERSGA, 2019). However, the last Red Sea status report authored by PERSGA was published a decade ago (2009) highlighting the urgent need to augment PERSGA's efforts and establish other scientific bodies and institutions that can standardize data collection protocols and support data collection programs and broad scientific research across the entire region. PERSGA's member states include Djibouti, Egypt, Jordan, the Kingdom of Saudi Arabia, Somalia, Sudan, and Yemen. However, both Eritrea, with over $1150 \mathrm{~km}$ of mainland Red Sea coastline and over 300 islands in addition, and Israel are excluded from participation.

It is important to note the vital scientific cooperation flourishing in the nearby Mediterranean Sea, which is connected to the Red Sea by the Suez Canal. The successful transnational monitoring in the Mediterranean Sea stands in contrast to the absence of international collaboration of monitoring activities along the Red Sea. The Mediterranean has a regional program run by the United Nations Environment Program (UNEP). It allows for standardization and data exchange between all 21 Mediterranean countries, including those with no diplomatic relations. The monitoring data is used by UNEP to set standards for seawater quality, which are agreed upon by all member countries of the Barcelona Convention (UNEP/MAP, 2016). Such agreed standards do not exist in the Red Sea, precluding comparison of data. UNEP also provides inter-calibration tests for all national monitoring laboratories in order to make sure all the chemical data is reliable. In the Red Sea region, only Jordan and Israel maintain continuous, ongoing, governmentmandated national monitoring programs along their entire coastlines, although these add up to less than $50 \mathrm{~km}$ of the total coastline of the Red Sea, i.e. less than 1\%. Jordan's and Israel's programs use different methods to collect data even for the same variables, however, making it difficult to compare or pool their data (Badran and Al Zibdah, 2005; The Jordan-Israel Monitoring Program in the Gulf of Aqaba [JIMP], 2005; The Israel National Monitoring Program at the Gulf of Eilat - Available Data, 2019). Only Israel's national monitoring data is publicly available online (The Israel National Monitoring Program at the Gulf of Eilat - Available Data, 2019). The joint Jordanian-Israeli monitoring activities have unfortunately declined to a minimal level over recent years.

Egypt has an annual monitoring program for marine resources and water quality along its coastline conducted by the Red Sea National Park Protectorate and the National Institute of Oceanography and fisheries (NIOF), although their data and reports are not available to the public (National Institute of Oceanography and Fisheries, 2019). There is periodic monitoring of substantial sections of the Saudi Arabian coastline by scientists at the King Abdullah University of Science and Technology (KAUST) Red Sea Research Center (Hadaidi et al., 2018; Monroe et al., 2018; Roik et al., 2018). PERSGA also conducts monitoring; it is contracted to assess sections of coastline in discrete projects by its 7 member states but not on a continuous basis. Some intermittent monitoring has also been completed by the Khaled bin Sultan Living Oceans Foundation, which is based in Saudi Arabia, and they published an atlas based on a 20062009 monitoring project undertaken at four sites along the Saudi coastline (Bruckner et al., 2012). Continuous, coordinated monitoring and conservation initiatives across the Red Sea's range from north to south has not been conducted yet, nor has transnational data been published regularly in recent years. But such data are invaluable to establish baseline levels in order to reliably track and detect change and conduct scientific research, especially in the context of rapid changes to ocean temperature and chemistry. Several of the countries bordering the Red Sea have only limited resources for monitoring or conservation activities, or for development of local scientific capacity. This can limit the feasibility of monitoring projects or research unless significant investment is made to expand resources for the local scientific community. 


\section{CURRENT LEVEL OF ESTABLISHED, FORMALIZED TRANSNATIONAL SCIENTIFIC RESEARCH IN THE REGION}

The examples of regional collaboration described above are focused primarily on monitoring and conservation in the Red Sea (Table 1). However, the newly formed Transnational Red Sea Center is focused on advancing the scientific study of the Red Sea ecosystem (A Research Center to Protect the Red Sea Ecosystem, 2019). A few centers devoted to transnational scientific research exist in the region, with one prominent example being the Synchrotron-light for Experimental Science and Applications in the Middle East (SESAME), an international center for scientific research centered around the region's first particle accelerator. Members include Egypt, Iran, Israel, and Jordan. Supported by the International Atomic Energy Agency, the center was inaugurated in Jordan in 2017 (IAEA, 2017). Also active in the region is the Middle East Desalination Research Center. It has a research program whose aim is to conduct, facilitate, and promote basic and applied research in the water desalination field, bringing together regional and global experts to collaborate. Headquartered in Oman, the Research Center also supplies training and promotes regional cooperation in this area (Middle East Desalination Research Center, 2019). The European Union has many transnational research collaboration networks. Some programs integrate scientific research and conservation, while others focus on enhancing the level of scientific work transnationally in order to increase Europe's competitiveness, support development of competences among researchers, coordinate scientific work across the region to achieve critical mass needed for strategic use of research resources, or enhance cross-disciplinary collaboration (Haegeman et al., 2014). The Transnational Red Sea Center will leverage Swiss expertise in science and diplomacy to examine these programs and design the optimal methods for initiating and sustaining effective regional cooperation in scientific study of the Red Sea ecosystem.

\section{EXPERT CONCLUSION}

Fourteen marine scientists who have worked in the region, as well as the ambassador of Switzerland to Israel, have contributed their perspectives on regional transnational scientific research, reef monitoring, and coordinated sciencebased reef management and conservation. Switzerland, a neutral country skilled in diplomacy and science and the host of the Transnational Red Sea Center, is an important supporter for these efforts. The researchers studied the Red Sea while based at institutions located in Australia, Germany, Israel, Jordan, Saudi Arabia, Switzerland, and the United States. Each scientist expressed nuanced views on a range of research programs, long-term monitoring methods, and reef conservation, as well as the opportunities and challenges for transnational scientific cooperation in the Red Sea region. While the topics covered were extensive, eight views were widely shared by the participating researchers. These were:

(1) Full regional scientific cooperation will require directives from high levels of government, although some scientists in the region already engage in active regional outreach.

(2) Political tensions between governments in the region present the main challenge to transnational scientific cooperation. A neutral partner should direct these efforts, fostering research cooperation, ensuring the use of standardized monitoring methods, verifying data quality, and making the data open for use by the public.

(3) To generate support for cooperation among all governments in the region it would be necessary to communicate:

(a) A strong economic argument demonstrating the monetary value of the reef to each nation. This was done in Egypt a decade ago, primarily for the Sinai coast (Cesar, 2003). The U.N. Environment Programme document UN Environment, ISU, ICRI, and Trucost (2018), titled The Coral Reef Economy - The business case for investment in the protection, preservation, and enhancement of coral reef health could be referred to as a valuable guide for this type of modeling;

(b) The high potential value of the development of antibiotics, probiotics, or other classes of therapeutics from biologically active materials found in the fauna and flora of coral reefs, or the myriad species of bacteria that live in the reef ecosystem;

TABLE 1 | Transnational Organizations active in the Red Sea.

\begin{tabular}{|c|c|c|c|c|c|}
\hline Transnational Organizations active in Red Sea & Countries & $\begin{array}{l}\text { Percent mainland } \\
\text { coastline }\end{array}$ & Established & $\begin{array}{l}\text { Supervising } \\
\text { Entity }\end{array}$ & Purpose \\
\hline $\begin{array}{l}\text { PERSGA, the Regional Organization for the } \\
\text { Conservation of the Environment of the Red Sea } \\
\text { and Gulf of Aden }\end{array}$ & $\begin{array}{l}\text { Djibouti Egypt } \\
\text { Jordan Saudi Arabia, } \\
\text { Somalia Sudan Yemen }\end{array}$ & $\sim 75 \%$ & 1995 & Arab League & $\begin{array}{l}\text { Monitoring, } \\
\text { conservation, } \\
\text { education }\end{array}$ \\
\hline $\begin{array}{l}\text { Joint Oil Spill Response Plan for the northern Gulf of } \\
\text { Aqaba }\end{array}$ & $\begin{array}{l}\text { Jordan } \\
\text { Israel }\end{array}$ & $\sim 1 \%$ & 1994 & $\begin{array}{l}\text { Jordanian and } \\
\text { Israeli governments }\end{array}$ & Conservation \\
\hline
\end{tabular}


(c) The Gulf of Aqaba is a unique natural sanctuary for corals and must be prioritized for immediate study as understanding these corals may represent the best hope for the future of global reefs;

(d) The urgent need for monitoring because of the threat to the Red Sea's reefs from population expansion along the coast and accompanying new development;

(e) A long-term regional monitoring program will support development of bioindicators of early stress in coral that precedes bleaching, which could be crucial for conservation managers in the Red Sea and around the world;

(f) The ongoing development of the Red Sea region must be accomplished sustainably.

(4) Variables tracked in the regional monitoring project must be measured using standardized methods, rather than relying on different participants to measure by their own protocols and instruments. Several scientists voiced concerns about how to implement monitoring with newer remotely operated vehicles or AUVs so as not to raise security concerns in the region. They felt that stationary remote sensing tools and water sampling stations would be better initial steps together with visual data collection by research diver surveys in order to build a picture of the entire Red Sea reef ecosystem.

(5) Data from regional monitoring should be made freely accessible to all in order to maximize the return on investment in a long-term program. Open access to a database maintained by a neutral institution could encourage participation by the different governments in the region. Some scientists were unsure whether all countries would send monitoring data outside of their national borders.

(6) Researchers and environmental managers must be able to analyze integrated, accurate data along the broad environmental gradients of the entire Red Sea from north to south and to assess differences between the east and west coasts.

(7) The capacity of local scientists and conservationists should be nurtured in order to help support a regional monitoring program and robust research and management initiatives. Local professionals not familiar with the monitoring approaches selected for the program should be trained and incentivized to take part to ensure its long-term success.

(8) Successful regional cooperation would require financial support from governments, the U.N., and large academic centers in order to reduce the chance of interruptions in funding and monitoring. Several scientists did point out that the lack of funds in some nations around the Red Sea would necessitate that their research and monitoring efforts be fully funded by outside sources.

\section{CALL TO ACTION}

We must act now to secure the Red Sea's coral reef for future generations. The corals that are thriving despite warming ocean temperatures are found only in the northernmost section of the Red Sea - i.e., in the Gulf of Aqaba. Bleaching has occurred in the Red Sea as far north as Hurghada (Furby et al., 2013; El-Askary et al., 2014; Monroe et al., 2018; Khaled, 2019). Therefore, the most urgent objective is to advance immediate protection of the Gulf of Aqaba as a World Heritage Site, with Egypt, Israel, Jordan, and Saudi Arabia as part of that initiative. Ideally, scientists, conservationists, and policy makers should advocate strongly that UNESCO recognize the Red Sea's entire coral reef as a Marine World Heritage site, as was proposed by Saudi Arabian delegates to the September 2019 UNESCO 4th World Heritage Marine Site conference (Arab News, 2019). At minimum, UNESCO should declare that specific portions of the Red Sea be recognized as Biosphere Reserves. Regional scientists and governments should work to involve UN scientists in the evaluation and implementation of regional monitoring and conservation efforts and seek UN support for a long-term scientific monitoring program.

A follow-up Transnational Red Sea Center conference should be held at EPFL so that senior representatives of the regional governments and leading coral research scientists could meet in a neutral setting to devise a strategy to achieve the above objectives. They should also begin defining the framework to facilitate collaborative research among the region's scientists. Methods must be devised for distribution of research support, joint publications and sharing of research facilities, technologies, and data. The Center welcomes the participation of all countries bordering the Red Sea.

Threats to the Red Sea's reef in its entirety, and to the uniquely resilient northernmost segment, are escalating, and we will need to work together to preserve them despite the many political and practical challenges. Otherwise, we will have to explain to future generations that we stood by as our generation destroyed one of the last reefs standing.

\section{AUTHOR CONTRIBUTIONS}

MF, KK, and AM contributed to conception and design of the study. KK wrote the first draft of the manuscript. AA-S, DB, AG, LG, OH-G, YL, AM, EO, J-DR, YS, CV, AZ, and MF provided data for the work. All authors contributed to manuscript revision, read and approved the submitted version.

\section{FUNDING}

The study was partially supported by a United States-Israel Binational Science Foundation grant no. 2016-403 to DB and MF and Israel Science Foundation grant no. 2979/19 to MF. 


\section{REFERENCES}

A Research Center to Protect the Red Sea Ecosystem (2019). Federal Department of Foreign Affairs (FDFA) / EPFL. Available at: https:// actu. epfl. ch/ news/ a-research- center- to- protect- the- red- sea- ecosystem/ (accessed October 15, 2019).

Al-Farawati, R. K., Gazzaz, M. O., El Sayed, M. A., and El-Maradny, A. (2011). Temporal and spatial distribution of dissolved $\mathrm{Cu}, \mathrm{Ni}$ and $\mathrm{Zn}$ in the coastal waters of Jeddah, Eastern Red Sea. Arab. J. Geosci. 4, 1229-1238. doi: 10.1007/ s12517-010-0137-y

Arab News (2019). Saudi Arabia Joins UNESCO Marine Heritage Conference. Available at: https://www.arabnews.com/node/1551701/saudi-arabia (accessed September 9, 2019).

Ateweberhan, M., Feary, D. A., Keshavmurthy, S., Chen, A., Schleyer, M. H., and Sheppard, C. R. (2013). Climate change impacts on coral reefs: synergies with local effects, possibilities for acclimation, and management implications. Mar. Pollut. Bull. 74, 526-539. doi: 10.1016/j.marpolbul.2013. 06.011

Ayla Oasis Development (2019). Avialble at: https://www.ayla.com.jo/en/ (accessed October 15, 2019).

Badran, M. I., and Al Zibdah, M. K. (2005). Quality standard codes of reference of jordanian coastal waters of the gulf of Aqaba, Red Sea. Chem. Ecol. 21, 337-350. doi: $10.1080 / 02757540500258831$

Barbière, J. (2019). Red Sea LME. Nairobi: UNEP.

Bellworthy, J., and Fine, M. (2017). Beyond peak summer temperatures, branching corals in the gulf of Aqaba are resilient to thermal stress but sensitive to high light. Coral Reefs 4, 1071-1082. doi: 10.1007/s00338-0171598-1

Berumen, M. L., Voolstra, C. R., Daffonchio, D., Agusti, S., Aranda, M., Irigoien, $\mathrm{X}$, et al. (2019). "The red sea: environmental gradients shape a natural laboratory in a Nascent Ocean," in Coral Reefs of the Red Sea, eds C. Voolstra, and M. Berumen, (Cham: Springer), 1-10. doi: 10.1007/978-3-030-058 02-9_1

Bozec, Y. M., and Mumby, P. J. (2015). Synergistic impacts of global warming on the resilience of coral reefs. Philos. Trans. R. Soc. B Biol. Sci. 370:20130267. doi: $10.1038 /$ srep 29778

Brinkhoff, T. (2017). Aqaba Governorate. City Population. Available at: https:// www.citypopulation.de/en/jordan/aqabah/ (accessed October 30, 2019).

Brinkhoff, T. (2019). Eilat. City Population. Available at: https://www. citypopulation.de/php/israel-admin.php?adm2id=2600 (accessed October 30, 2019).

Bruckner, A., Rowlands, G., Riegl, B., Purkis, S., Williams, A., and Renaud, P. (2012). Khaled Bin Sultan Living Oceans Foundation Atlas of Saudi Arabian Red Sea Marine Habitats. Arizona: Panoramic Press.

Bruckner, A. W. (2002). Life-saving products from coral reefs. Issues Sci. Technol. $18,39-44$.

Burke, L., Reytar, K., Spalding, M., and Perry, A. (2011). Reefs at Risk Revisited. Washington, DC: World Resources Institute.

Cesar, H. (2003). Economic Valuation of the Egyptian Red Sea Coral Reef. Washington, DC: United States Agency for International Development.

Dibattista, J. D., Roberts, M. B., Bouwmeester, J., Bowen, B. W., Coker, D. J., Lozano-Cortés, D. F., et al. (2016). A review of contemporary patterns of endemism for shallow water reef fauna in the Red Sea. J. Biogeogr. 43, 423-439. doi: 10.1111/jbi.12649

El-Askary, H., Abd El-Mawla, S. H., Li, J., El-Hattab, M. M., and El-Raey, M. (2014). Change detection of coral reef habitat using landsat-5 TM, landsat 7 ETM+ and landsat 8 OLI data in the Red Sea (Hurghada, Egypt). Int. J. Remote Sens. 35, 2327-2346. doi: 10.1080/01431161.2014.894656

Eyal, G., Tamir, R., Kramer, N., Eyal-Shaham, L., and Loya, Y. (2019). "The Red Sea:Israel," in Mesophotic Coral Ecosystems, eds K. A. Loya, Y. Bridge, and T. C. L. Puglise, (Switzerland: Springer).

Fine, M., Cinar, M., Voolstra, C. R., Safa, A., Rinkevich, B., Laffoley, D., et al. (2019). Coral reefs of the Red Sea - challenges and potential solutions. Reg. Stud Mar. Sci. 25:100498. doi: 10.1016/j.rsma.2018.100498

Fine, M., Gildor, H., and Genin, A. (2013). A coral reef refuge in the red sea. Glob. Chang. Biol. 19, 3640-3647. doi: 10.1111/gcb.12356

Fischhendler, I., and Tenenboim-Weinblatt, K. (2019). The peace dividend as an intangible benefit in mega-project justification: a comparative content analysis of the dead sea-red sea Canal. Geoforum 101, 141-149. doi: 10.1016/j.geoforum. 2019.01.016
Furby, K. A., Bouwmeester, J., and Berumen, M. L. (2013). Susceptibility of central red sea corals during a major bleaching event. Coral Reefs 32, 505-513. doi: 10.1007/s00338-012-0998-5

Genevier, L. G. C., Jamil, T., Raitsos, D. E., Krokos, G., and Hoteit, I. (2019). Marine heatwaves reveal coral reef zones susceptible to bleaching in the Red Sea. Glob. Chang. Biol. 25, 2338-2351. doi: 10.1111/gcb.14652

Grottoli, A. G., Tchernov, D., and Winters, G. (2017). Physiological and biogeochemical responses of super-corals to thermal stress from the northern gulf of Aqaba, Red Sea. Front. Mar. Sci. 4:215. doi: 10.3389/fmars.2017.00215

Hadaidi, G., Ziegler, M., Shore-Maggio, A., Jensen, T., Aeby, G., and Voolstra, C. R. (2018). Ecological and molecular characterization of a coral black band disease outbreak in the Red Sea during a bleaching event. PeerJ 6:e5169. doi: 10.7717/peerj.5169

Haegeman, K., Harrap, N., Boden, M., and Özbolat, N. (2014). Added Value of Transnational Research Programming: Lessons from Longstanding Programme Collaborations in Europe. Luxembourg: Publications Office of the European Union.

Hoegh-Guldberg, O. (2011). Coral reef ecosystems and anthropogenic climate change. Reg. Environ. Chang. 11, 215-227. doi: 10.1007/s10113-010-0189-2

Hughes, T. P., and Connell, J. H. (1999). Multiple stressors on coral reefs: a longterm perspective. Limnol. Oceanogr. 44, 932-940. doi: 10.1038/s41467-019$12431-y$

IAEA (2017). IAEA-Backed SESAME Research Centre Opens Its Doors, Fostering Scientific Cooperation in the Middle East. Available at: https://www.iaea.org/newscenter/pressreleases/iaea-backed-sesame-researchcentre-opens-its-doors-fostering-scientific-cooperation-in-the-middle-east (accessed October 20, 2019).

Ibrahim, H. A. H., El-Naggar, H. A., El-Damhougy, K. A., Bashar, M. A. E., and Abou Senna, F. M. (2017). Callyspongia crassa and C. siphonella (Porifera, Callyspongiidae) as a potential source for medical bioactive substances, Aqaba Gulf, Red Sea, Egypt. J. Basic Appl. Zool. 78:7.

Khaled, M. (2019). Using landsat data to assess the status of coral reefs cover along the Red Sea Coast, Egypt. Int. J. Ecotoxicol. Ecobiol. 4, 17-31.

Kremb, S., Müller, C., Schmitt-Kopplin, P., and Voolstra, C. R. (2017). Bioactive potential of marine macroalgae from the Central Red Sea (Saudi Arabia) assessed by high-throughput imaging-based phenotypic profiling. Mar. Drugs 15:E80. doi: 10.3390/md15030080

Krokos, G., Papadopoulos, V. P., Sofianos, S. S., Ombao, H., Dybczak, P., and Hoteit, I. (2019). Natural climate oscillations may counteract red sea warming over the coming decades. Geophys. Res. Lett. 46, 3454-3461. doi: 10.1029/ 2018 gl081397

Krueger, T., Horwitz, N., Bodin, J., Giovani, M. E., Escrig, S., Meibom, A., et al. (2017). Common reef-building coral in the northern red sea resistant to elevated temperature and acidification. R. Soc. Open Sci. 4, 170038. doi: 10.1098/rsos. 170038

Loya, Y., Lubinevsky, H., Rosenfeld, M., and Kramarsky-Winter, E. (2004). Nutrient enrichment caused by in situ fish farms at eilat, red sea is detrimental to coral reproduction. Mar. Pollut. Bull. 49, 344-353. doi: 10.1016/j.marpolbul. 2004.06.011

Malve, H. (2016). Exploring the ocean for new drug developments: marine pharmacology. J. Pharm. Bioallied Sci. 8, 83-91. doi: 10.4103/0975-7406.171700

Middle East Desalination Research Center (2019). Available at: https://www.medrc. org/ (accessed October 30, 2019).

Monroe, A. A., Ziegler, M., Roik, A., Röthig, T., Hardenstine, R. S., Emms, M. A., et al. (2018). In Situ observations of coral bleaching in the Central Saudi Arabian Red Sea during the 2015/2016 global coral bleaching event. PLoS One 13:e0195814. doi: 10.1371/journal.pone.0195814

National Institute of Oceanography and Fisheries (2019). Available at: http://www. niof.sci.eg/ (accessed October 30, 2019).

Neom (2019). Available at: https://www.neom.com/en-us/about/\#facts (accessed October 20, 2019).

NOAA (2019a). Coral Reef Ecosystems. Available at: https://www.noaa.gov/ education/resource-collections/marine-life-education-resources/coral-reefecosystems (accessed October 20, 2019)

NOAA (2019b). Importance of Coral Reefs. Silver Spring, MA: National Oceanic and Atmospheric Administration.

O’Rourke, A., Kremb, S., Bader, T. M., Helfer, M., Schmitt-Kopplin, P., Gerwick, W. H., et al. (2016). Alkaloids from the sponge Stylissa carteri present prospective scaffolds for the inhibition of human immunodeficiency virus 1 (HIV-1). Mar. Drugs 14:E28. doi: 10.3390/md14020028 
O’Rourke, A., Kremb, S., Duggan, B. M., Sioud, S., Kharbatia, N., Raji, M., et al. (2018). Identification of a 3-alkylpyridinium compound from the Red Sea sponge amphimedon chloros with in vitro inhibitory activity against the West Nile virus NS3 protease. Molecules 23:E1472. doi: 10.3390/molecules23061472

Osman, E. O., Smith, D. J., Ziegler, M., Kürten, B., Conrad, C., El-Haddad, K. M., et al. (2018). Thermal refugia against coral bleaching throughout the Northern Red Sea. Glob. Chang. Biol. 24, e474-e484. doi: 10.1111/gcb.13895

Osman, E. O., Suggett, D. J., Voolstra, C. R., Petta, D. T., Clark, D. R., Pogoreutz, C., et al. (2020). Coral microbiome composition along the northern Red Sea suggests high plasticity of bacterial and specificity of endosymbiotic dinoflagellate communities. Microbiome 8, 1-16. doi: 10.1186/s40168-0190776-5

PERSGA (2019). Available at: http://www.persga.org/ (accessed October 20, 2019).

Portman, M. E., and Teff-Seker, Y. (2017). Factors of success and failure for transboundary environmental cooperation: projects in the Gulf of Aqaba. J. Environ. Policy Plann. 19, 810-826. doi: 10.1080/1523908x.2017.1292873

Ras Mohammed National Park (2019). Atlas of Marine Protection. Available at: http://www.mpatlas.org/mpa/sites/758/ (accessed October 22, 2019).

Red Sea The Project (2019). Available at: https://www.theredsea.sa/en/project (accessed October 20, 2019).

Red Sea-Dead Sea Water Conveyance Study Environmental and Social Assessment (2014). Available at: http://siteresources.worldbank.org/ EXTREDSEADEADSEA/Resources/5174616-1416839444345/ESA_ES_ Mar_2014_English.pdf (accessed October 30, 2019).

Roder, C., Berumen, M. L., Bouwmeester, J., Papathanassiou, E., Al-Suwailem, A., and Voolstra, C. R. (2013). First biological measurements of deep-sea corals from the Red Sea. Sci. Rep. 3:2802. doi: 10.1038/srep02802

Roik, A., Röthig, T., Pogoreutz, C., Saderne, V., and Voolstra, C. R. (2018). Coral reef carbonate budgets and ecological drivers in the central Red Sea - a naturally high temperature and high total alkalinity environment. Biogeosciences 15, 6277-6296. doi: 10.5194/bg-15-6277-2018

Shaala, L. A., Youssef, D. T. A., Badr, J. M., Sulaiman, M., and Khedr, A. (2015). Bioactive secondary metabolites from the red sea marine verongid sponge suberea species. Mar. Drugs 13, 1621-1631. doi: 10.3390/md13041621

Shlesinger, T., and Loya, Y. (2019). Breakdown in spawning synchrony: a silent threat to coral persistence. Science 365, 1002-1007. doi: 10.1126/science. aax 0110

Steiner, Z., Turchyn, A. V., Harpaz, E., and Silverman, J. (2018). Water chemistry reveals a significant decline in coral calcification rates in the southern Red Sea. Nat. Commun. 9:3615. doi: 10.1038/s41467-018-06030-6

Suez Canal Traffic Statistics Annual Report 2018 (2019) Available at: https://www.suezcanal.gov.eg/English/Downloads/DownloadsDocLibrary/ NavigationReports/AnnualReports???/2018.pdf (accessed October 30, 2019).

The Israel National Monitoring Program at the Gulf of Eilat - Available Data (2019). InterUniversity Institute for Marine Sciences. Available at: https://iuieilat.huji.ac.il/Research/NMPMeteoData.aspx (accessed October 30, 2019).
The Jordan-Israel Monitoring Program in the Gulf of Aqaba [JIMP] (2005). Available at: http://www.sviva.gov.il/English/env_topics/ marineandcoastalenvironment/Documents/IsraelJordanMonitoringProgramGulfOfAqaba-Summary2005.pdf (accessed October 30, 2019).

UN Environment, ISU, ICRI, and Trucost (2018). The Coral Reef Economy: The Business Case for Investment in the Protection, Preservation and Enhancement of Coral Reef Health. 36. Available at: http://wedocs.unep. org/xmlui/bitstream/handle/20.500.11822/26694/Coral_Reef_Economy.pdf? sequence $=1$ \&isAllowed $=y$ (accessed 10 April 10, 2019).

UNEP/MAP (2016). Integrated Monitoring, and Assessment Programme of the Mediterranean Sea, and Coast, and Related Assessment Criteria. Athens: UNEP.

Voolstra, C. R., and Berumen, M. L. (eds) (2019). Coral Reefs of the Red Sea. Cham: Springer.

Whitman, E. (2019). A land without water: the scramble to stop jordan from running dry. Nature 573, 20-23. doi: 10.1038/d41586-019-02600-w

Wintour, P. (2019). Iranian Oil Tanker Damaged by Explosions near Saudi Port City. Available at: https://www.theguardian.com/world/2019/oct/11/iranianoil-tanker-on-fire-after-blast-near-saudi-port-city-report (accessed October 11, 2019).

World Maritime News (2019). Houthis Seeking Help to Prevent Massive Oil Spill off Yemen from Leaking FSO. Available at: https://worldmaritimenews.com/ archives/288102/report-houthis-seeking-help-to-prevent-massive-oil-spilloff-yemen-from-leaking-fso/ (accessed December 17, 2019).

Ziegler, M., Grupstra, C. G. B., Barreto, M. M., Eaton, M., BaOmar, J., Zubier, K., et al. (2019). Coral bacterial community structure responds to environmental change in a host-specific manner. Nat. Commun. 10:3092. doi: 10.1038/s41467019-10969-5

Ziegler, M., Roik, A., Porter, A., Zubier, K., Mudarris, M. S., Ormond, R., et al. (2016). Coral microbial community dynamics in response to anthropogenic impacts near a major city in the central Red Sea. Mar. Pollut. Bull. 105, 629-640. doi: 10.1016/j.marpolbul.2015.12.045

Conflict of Interest: The authors declare that the research was conducted in the absence of any commercial or financial relationships that could be construed as a potential conflict of interest.

The handling Editor declared a past co-authorship with one of the authors CV.

Copyright (c) 2020 Kleinhaus, Al-Sawalmih, Barshis, Genin, Grace, Hoegh-Guldberg, Loya, Meibom, Osman, Ruch, Shaked, Voolstra, Zvuloni and Fine. This is an openaccess article distributed under the terms of the Creative Commons Attribution License (CC BY). The use, distribution or reproduction in other forums is permitted, provided the original author(s) and the copyright owner(s) are credited and that the original publication in this journal is cited, in accordance with accepted academic practice. No use, distribution or reproduction is permitted which does not comply with these terms. 